\title{
Headache and pleocytosis in CSF associated with COVID-19: case report
}

\author{
Felipe Araújo Andrade de Oliveira ${ }^{1,2}\left[\right.$ D $\cdot$ Danylo César Correia Palmeira ${ }^{1,2} \cdot$ Pedro Augusto Sampaio Rocha-Filho $^{2}$
}

Received: 20 July 2020 / Accepted: 28 August 2020 / Published online: 2 September 2020

(C) Fondazione Società Italiana di Neurologia 2020

\begin{abstract}
In December 2019, a new coronavirus infection was identified in China. Although the clinical presentation of COVID-19 is predominantly respiratory, more than $35 \% \%$ of patients have neurological symptoms. We report an elderly female with asthenia, dry cough, anosmia, ageusia, fever, nausea, and a severe and persistent headache. She had confirmed COVID-19 using the nasal swab RT-PCR technique. Her cranial tomography was normal. The CSF analysis demonstrated a cell count of $21 \mathrm{cells} / \mathrm{mm}^{3}$ ( $80 \%$ lymphocytes and $20 \%$ monocytes), $34 \mathrm{mg} / \mathrm{dl}$ protein, and $79 \mathrm{mg} / \mathrm{dl}$ glucose. She improved after 4 days. Our report draws attention to the meningeal involvement of SARS-Cov-2.
\end{abstract}

Keywords COVID-19 $\cdot$ SARS-CoV-2 $\cdot$ Meningitis $\cdot$ Headache $\cdot$ Headache disorders, secondary

\section{Introduction}

In December 2019, a new coronavirus infection (COVID-19) was identified in China. Although the clinical presentation of COVID-19 is predominantly respiratory, more than $35 \%$ of patients have neurological symptoms [1].

We searched PubMed and SciELO (Scientific Electronic Library Online) for observational studies published between December 2019 and July 2020, with the search terms: COVID-19 OR SARS-CoV-2 AND meningitis. We did not find any case report about isolated viral meningitis associated with COVID-19.

We describe herein a case of a patient with isolated viral meningitis associated with COVID-19.

\section{Case report}

A 68-year-old female with systemic arterial hypertension presented with a dry cough, anosmia, and ageusia for 7 days. She

Felipe Araújo Andrade de Oliveira

felipe.oliveira1983@gmail.com

1 Real Hospital Português de Beneficência de Pernambuco, Recife, Brazil

2 Universidade Federal de Pernambuco, Recife, Brazil also had a fever in the first 7 days of symptoms. After an improvement in these symptoms, the patient began to present asthenia, nausea, and a severe headache.

This headache had a gradual onset, a severe intensity; was located in the left frontotemporal region; was described as a dull/stabbing pain; and was associated with nausea. There was no vomiting and no photophobia, phonophobia, or associated autonomic trigeminal symptoms. Her headache was continuous, with no remission periods, and lasted 8 days.

Her physical examination was normal, with a temperature of $36.7^{\circ} \mathrm{C}$, a respiratory rate of 18 incursions per minute, and $97 \% \mathrm{O}_{2}$ saturation in ambient air.

On neurological examination, she presented no change in the level or content of consciousness or meningeal signs or focal signs. In the laboratory exams on admission, she presented lymphopenia (540 lymphocytes/mm3), thrombocytopenia $(117,000$ platelets $/ \mathrm{mm} 3)$, and 7.61 C-reactive protein (normal up to $0.03 \mathrm{mg} / \mathrm{dl}$ ).

On admission, due to the persistence of a severe headache and nausea, she underwent a non-contrast cranial tomography, which was normal, and a lumbar puncture. The CSF analysis demonstrated a cell count of 21 cells $/ \mathrm{mm}^{3}$ (80\% lymphocytes and $20 \%$ monocytes), $34 \mathrm{mg} / \mathrm{dl}$ protein, and $79 \mathrm{mg} / \mathrm{dl}$ glucose. The CSF opening pressure was $20 \mathrm{cmH}_{2} \mathrm{O}$.

The result of the COVID-19 survey was positive, using the nasal swab RT-PCR technique. The CSF was not tested for the virus. 
The patient remained in the hospital for 4 days and was discharged after clinical improvement.

\section{Discussion}

Our patient had a fever, severe headache, nausea, and lymphocytic pleocytosis in the CSF. This clinical picture is compatible with viral meningitis. The CSF cellularity, although increased, had a relatively low value. This can be explained by the time this test was performed, after 12 days of symptoms.

The positivity of RT-PCR in the presence of symptoms reinforces the possibility that the cause of meningitis was SARS-CoV-2. However, we may not rule out the possibility of coinfection with other viruses. We encountered no description in the literature of viral meningitis associated with COVID-19.

Thus far, little is known on the neurological impairment caused by SARS-CoV-2. Recently, the description of cases of meningoencephalitis [2-4] and Guillain-Barré syndrome $[5,6]$ reinforced the possibility of affecting both the central nervous system and the peripheral nervous system in COVID19.

Headache can be a major problem for patients with COVID-19 [7]. Mao et al. reported that 28 of 214 patients (13\%) admitted to Chinese hospitals presented with headache [8]. As no CSF was performed, the possibility that this headache was caused by viral meningitis cannot be ruled out. Recently, two studies performed by neurologists found higher frequencies of headaches (27 and 45\%) [9, 10].

Little is known about the pathophysiology of headache in patients with COVID-19. It is speculated that a direct lesion of the virus or the inflammatory process triggered by it may be involved [7]. Headache patients have a higher serum level of interleukin 6 than those without headaches [9].

Our report, therefore, draws attention to the meningeal involvement in the pathophysiology of headache and shows that even in a patient without meningeal signs but with persistent headache, the possibility of viral meningitis should be considered.

\section{Compliance with ethical standards}

Conflict of interest The authors declare that they have no conflict of interest.

Ethical approval This case report was approved by the institution's ethics committee.
Disclaimer The authors declare that the proposed manuscript describes original research and is not published or under consideration by another scientific journal. The data/results of the manuscript are not plagiarized.

\section{References}

1. Niazkar HR, Zibaee B, Nasimi A, Bahri N (2020) The neurological manifestations of COVID-19: a review article. Neurol Sci 41(7): 1667-1671. https://doi.org/10.1007/s10072-020-04486-3

2. Moriguchi T, Harii N, Goto J, Harada D, Sugawara H, Takamino J, Ueno M, Sakata H, Kondo K, Myose N, Nakao A, Takeda M, Haro H, Inoue O, Suzuki-Inoue K, Kubokawa K, Ogihara S, Sasaki T, Kinouchi H, Kojin H, Ito M, Onishi H, Shimizu T, Sasaki Y, Enomoto N, Ishihara H, Furuya S, Yamamoto T, Shimada S (2020) A first case of meningitis/encephalitis associated with SARS-Coronavirus-2. Int J Infect Dis 94:55-58. https://doi.org/ 10.1016/j.ijid.2020.03.062

3. Yin R, Feng W, Wang T, Chen G, Wu T, Chen D, Lv T, Xiang D (2020) Concomitant neurological symptoms observed in a patient diagnosed with coronavirus disease 2019. J Med Virol. https://doi. org/10.1002/jmv. 25888

4. Bernard-Valnet R, Pizzarotti B, Anichini A, Demars Y, Russo E, Schmidhauser M, Cerutti-Sola J, Rossetti AO, Du Pasquier R (2020) Two patients with acute meningo-encephalitis concomitant to SARS-CoV-2 infection. Eur J Neurol 27. https://doi.org/10. 1111/ene. 14298

5. Zhao H, Shen D, Zhou H, Liu J, Chen S (2020) Guillain-Barre syndrome associated with SARS-CoV-2 infection: causality or coincidence? Lancet Neurol 19:383-384. https://doi.org/10.1016/ s1474-4422(20)30109-5

6. Zito A, Alfonsi E, Gastaldi M, Ceroni M, Costa A (2020) COVID19 and Guillain-Barré syndrome: a case report and review of literature. Front Neurol 11. https://doi.org/10.3389/fneur.2020.00909

7. Sampaio Rocha-Filho PA, Voss L (2020) Persistent headache and persistent anosmia associated with COVID-19. Headache. https:// doi.org/10.1111/head.13941

8. Mao L, Jin H, Wang M, Hu Y, Chen S, He Q, Chang J, Hong C, Zhou Y, Wang D, Miao X, Li Y, Hu B (2020) Neurologic manifestations of hospitalized patients with coronavirus disease 2019 in Wuhan, China. JAMA Neurol 77:683. https://doi.org/10.1001/ jamaneurol.2020.1127

9. Karadaş Ö, Öztürk B, Sonkaya AR (2020) A prospective clinical study of detailed neurological manifestations in patients with COVID-19. Neurol Sci 41(8):1991-1995. https://doi.org/10.1007/ s10072-020-04547-7

10. Vacchiano V, Riguzzi P, Volpi L, Tappatà M, Avoni P, Rizzo G, Guerra L, Zaccaroni S, Cortelli P, Michelucci R, Liguori R (2020) Early neurological manifestations of hospitalized COVID-19 patients. Neurol Sci 41(8):2029-2031. https://doi.org/10.1007/ s10072-020-04525-Z

Publisher's note Springer Nature remains neutral with regard to jurisdictional claims in published maps and institutional affiliations. 